Journal of Southeast Asian

Volume 15

Issue 2 Voices from the Field: Centering

Southeast Asian Americans through Policy,

Article 1

Practice, and Activism

2020

\title{
Special Issue Editors' Introduction: Voices from the Field: Centering Southeast Asian Americans through Policy, Practice, and Activism
}

\author{
Loan Thi Dao \\ St. Mary's College of California, Itd2@stmarys-ca.edu \\ Peter T. Keo \\ Stanford University, peterkeo@g.ucla.edu
}

Follow this and additional works at: https://docs.lib.purdue.edu/jsaaea

Part of the Bilingual, Multilingual, and Multicultural Education Commons, Educational Administration and Supervision Commons, Educational Leadership Commons, and the Social and Behavioral Sciences Commons

\section{Recommended Citation}

Dao, Loan Thi and Keo, Peter T. (2020) "Special Issue Editors' Introduction: Voices from the Field: Centering Southeast Asian Americans through Policy, Practice, and Activism," Journal of Southeast Asian American Education and Advancement. Vol. 15 : Iss. 2, Article 1.

DOI: 10.7771/2153-8999.1211

Available at: https://docs.lib.purdue.edu/jsaaea/vol15/iss2/1

This document has been made available through Purdue e-Pubs, a service of the Purdue University Libraries. Please contact epubs@purdue.edu for additional information.

This is an Open Access journal. This means that it uses a funding model that does not charge readers or their institutions for access. Readers may freely read, download, copy, distribute, print, search, or link to the full texts of articles. This journal is covered under the CC BY-NC-ND license. 


\title{
JSAAEA Journal of Southeast Asian American
Education and Advancement
}

Vol. 15 Iss. 2 Special Issue (2020) www.JSAAEA.org

\author{
Special Issue Editors' Introduction
}

\section{Voices from the Field: Centering Southeast Asian Americans through Policy, Practice, and Activism}

\author{
Loan Thi Dao \\ St. Mary's College of California \\ Peter T. Keo \\ Stanford University
}

\begin{abstract}
As we commemorate the $45^{\text {th }}$ anniversary of the end of the American war in Cambodia, Laos, and Viet Nam, we face a critical moment in our history as a part of historical debates about the heart and soul of this country that invites an imagination of our collective future through the frames of social justice. Voices from the Field centers on the fluid, dynamic, and multidimensional locations of Southeast Asian American voices across educational policy, practice, leadership, and activism at the confluence of pan-ethnic and inter-racial solidarity and educational justice. At this critical juncture in Asian Pacific American (APA) history, this special issue offers opportunities to understand how educational institutions, policies, and curriculum must confront the problematic ways in which Southeast Asian Americans have been essentialized, rendered simultaneously invisible and hyper-visible, and contained into sterilized narratives as refugee victims in need of educational salvation to earn their place as "Model Minorities." The contributors to this issue provide critical interventions in the areas of education policy, curricular development that reflects and supports the diversity of Southeast Asian American students today, the intersectional challenges and barriers for first-generation students and for emerging leaders. It urges the reader to consider the re-connection of community and activism as a critical intervention to historical attempts to sever organic identities and community ties from the goals and measurable successes of schooling. This issue attempts to move beyond the broad articulations of Asian Americans in education that (academically) essentializes Southeast Asian American educators, students, and communities to invest in approaches and curriculum that honors our unique and complex stories of trauma, survival, resilience into the twenty-first century. It is critical to recognize the unique and nuanced history, experience, culture, agency, and contributions of Southeast Asian Americans - one that is often rendered invisible under the pan-ethnic category of Asian Americans or essentialized as pathologically "at risk." The contributors to this issue are using interdisciplinary, transnational approaches to map critical sites of educational justice that is community-driven, healing, and transformative. Their essays emphasize the need for counter-

\footnotetext{
@)

SDRERIIGHISRESERNEDR Readers are free to copy, display, and distribute this article, as long as the work is attributed to the author(s) and the Journal of Southeast Asian American Education \& Advancement, it is distributed for non-commercial purposes only, and no alteration or transformation is made in the work. More details of this Creative Commons license are available at http://creativecommons.org/licenses/by-nc-nd/3.0/. All other uses must be approved by the author(s) or JSAAEA.

Journal of Southeast Asian American Education \& Advancement, Vol. 15. Iss. 2. (2020) ISSN: 2153-8999
} 
narratives that shape intergenerational refugee communities not as problems to be fixed but rather as critical sites of inquiry that need and deserve to be heard.

Evidence suggests that educational success portends success in other life outcomes including socio-economic mobility. It is well documented that investing in formal education often yields stronger earning potential. In essence, a college graduate generally has more potential to earn a higher income than someone with only a high school diploma. However, the challenge with extant research on K-20 education is that it often bifurcates Southeast Asian Americans into categories of academic success or failure. This categorization does not capture the complex, fluid, and varied lived experiences of individuals defined neither by success nor failure. Therefore, we were interested in the following questions: What are the different ways of knowing and being beyond success or failure among Southeast Asian Americans in the structures and curriculum of K-20 education? What are the barriers and opportunities for Southeast Asian Americans in navigating the leadership pipeline to sit at the decision-making tables? How do we understand and prioritize the intersectional lives of our students and their families beyond these metrics of academic achievement to transformative social justice that breaks down the walls of schooling, community, class, and race and ethnicity so that both educators and students bring our holistic selves to classroom with the goal to realize a vision of a new world?

Voices from the Field emphasizes these themes through contributors who work at the crossroads of research and practice as educators, school leaders and activists. Scholars responded to an open call for peer-reviewed submissions while advocates and practitioners were invited to submit essays. In light of recent events that put in relief the difficult racial dynamics related to COVID-19, the Black Lives Matter movement, and the particular murder of George Floyd, we received permission to reprint a statement by a coalition of organizations, led by CAALMinnesota, and a self-reflection by Minnesota resident Cameron PajYeeb Yang. The contributions have been divided into three overlapping areas of educational policy and curricular practices, intersectional leadership, and advocacy and activism in the historical moment. Peter T. Keo and Mike Hoa Nguyen provide the landscape of educational policy that paves the discussion for Yvonne Kwan and Mary Yee to offer critical interventions to curriculum that speak to holistic and transformative educational opportunities for Cambodian American and first-generation Vietnamese American students. Van T. Lac, Seng-Dao Yang Keo, and Jia Grace Liang extend the themes of marginalization and potential of students into the obstacles of Southeast Asian women faculty and administrators. The contributions of SEARAC, CAAL-MN, and Cameron PajYeeb Yang remind us of what is at stake for us as communities to more deeply understand ourselves within the historical hegemonic paradigms of our adopted homelands in order to truly engage in transformative education that builds a more just tomorrow.

Dr. Peter T. Keo's article examines how Southeast Asian Americans are treated in leading K-12 and higher educational research. His qualitative meta-analysis of 151 peer-reviewed academic articles in six K-12 and higher education journals over ten years (2007-2016) resulted in only four of the 151 articles (2.6\%) reviewed specifically addressed in whole or in part Southeast Asian Americans. Findings demonstrate that aggregating racial data for Asian Americans silences under-represented Southeast Asian Americans. Dr. Mike Hoa Nguyen's article extends the concerns of lack of representation and disaggregated data into higher education that led to advocacy for federal designation as Minority Serving Institutions (MSI) for APAs. He highlights how the Asian American and Native American Pacific Islander Serving Institutions (AANAPISI) programs can intentionally design their higher educational programming to support Southeast Asian American students, and their responsibility in effectively advocating for them at the policy 
level. Dr. Nguyen's article provided a background and an overview of the AANAPISI landscape over the past decade that lays the foundational potential for more expansive integration of lowincome Southeast Asian American students to enter higher education and exploration of critical innovations to help these students thrive.

Dr. Yvonne Kwan explores the complexities of young Cambodian American refugee subjecthood as it is informed by historical trauma and reproduced trauma in the daily lives of students. She documents how Cambodian American students navigate through dominant discursive narratives about their racial and ethnic identity to then form identities reflective of their lived experiences. The students in her research position themselves not as refugee victims but as subjects of their own identity formation. Kwan advocates for higher education practitioners to support and nurture this process for students by exploring a deeper understanding of their challenges and strengths as members of a refugee diaspora. Dr. Mary Yee builds on past calls for relevant curriculum that centers student identities in transformative education in her example of first-generation students' return to Viet Nam through their courses. First-generation students who reported feeling a sense of liminality in American as well as Asian American spaces on campus found a sense of validation and relevance in these educational trips. And yet, they simultaneously had to complicate notions of home and identity as they saw their country of birth through a critical academic lens and as "visitors." The experiences forced them to reckon with the ways in which they were now viewed by locals as "Việt Kiều," or "overseas Vietnamese." This self-reflection of their imagined community sterilized in memory contrasted with the reality of their evolving positionality in the global and temporal terrains that Southeast Asian American studies must continue to unpack with new generations and with continual, cyclical migration.

Dr. Van T. Lac's essay segues into topics of intersectional leadership and activism both in and beyond educational settings. She focuses on the themes of (dis)placement and (in)visibility she has encountered as a Southeast Asian refugee youth navigating the educational systems in K12 public schools and in higher education from an undergraduate student to a professor. Her essay highlights the challenges of many Southeast Asian American scholars who enter higher education where the model minority myth shapes in both explicit and veiled ways in the process of educational achievement, seeking mentorship and models, and attaining tenure. Dr. Seng-Dao Yang Keo's essay examines the intersection of race, ethnicity, and gender as a first-generation Hmong-American woman in a senior-level K-12 educational leadership policy role. Dr. Yang Keo shares her story of resistance and resilience as she navigates different educational and workforce systems as the child of a Hmong child solider and middle school graduates. Dr. Jia Grace Liang's study draws on accounts of two Vietnamese American women school administrators in a Southern state and a Midwestern state to understand the ways in which they have navigated intersectional stereotypes to advocate for equity and inclusion for their socio-culturally and linguistically diverse students and families. As institutional administrators in geographical areas with small APA populations, their resilience, intellect, and creativity paved the way for conditions for access to, advancement in, and enactment of substantive change in educational advocacy.

We close this issue with voices from community leaders on the front lines in the struggle for representation, leadership development, community-building and advocacy. At the national level, the Southeast Asian Resource Action Center (SEARAC) has been at the helm for Southeast Asian American communities. They have demanded a seat at the decision-making tables since refugee resettlement in the 1970s, advocating for the rights and needs of refugees and the diasporic community in the United States. Executive Director Quyen Dinh and staff members Katrina D. Mariategue and Anna H. Byon share the current state of Southeast Asian American communities 
and a roadmap to advocate for equity and justice in the areas of education, economics, and immigration. We also have permission from the Center for Asian-American Leaders (CAAL) Minnesota to reprint their open letter regarding the death of George Floyd, their call for solidarity with Black Lives Matter, and their analysis of the positionality of Southeast Asian Americans in the national conversation on race and racism. Cameron PajYeeb Yang deepens CAAL's push for a critical reflection of anti-blackness in our communities in their first-person narrative of the impact of toxic masculinity, homophobia, and transphobia within our communities and in our society that must be grappled with in light of the disproportionate murders of trans people of color. We are grateful to them for their willingness to share their thoughts in the context of Pride and the anniversary of the Stonewall riots.

In the midst of all the challenges we face in this moment, Southeast Asian Americans, as part of Asian Pacific American (APA) pan-ethnic community, are both on the front lines of relief efforts and the targets of hate speech and hate crimes across the country. We are the essential workers in healthcare, food, and other industries. So many of our community members also rely heavily on small business "mom and pop" shops as a means of economic mobility, such as beauty salons, restaurants, and other service-based businesses. Their closures translate into potential economic devastation for many families, who have little or no access to institutional safety nets, including adequate access to healthcare in many states. Yet, the public statements by government leaders and across social media in recent months have escalated into negative attitudes, hate speech, and even physical violence to APA-owned businesses, homes, and individuals of all ages. Unfortunately, these attitudes and behaviors have been part of a long history of anti-APA sentiment in this country since the 1800s. It has resulted in forced segregation and the burning of APA enclaves, physical violence and murders of APIs, and policies and laws that were overtly targeted at APA communities. The continual, unrestrained repetition of stereotypes in popular culture, academic research, and from leaders have reproduced these behaviors throughout our history and in the current crisis. These stereotypes include:

1) Model Minorities: assuming APAs are all wealthy and self-sufficient, passive and docile, and thus not needing help or support;

2) Yellow Peril: viewing APAs as a threat by carrying disease; as being moral and criminal threats; as always loyal to "Asia" rather than the United States; as intentionally "stealing" American jobs, wealth, educational opportunities to our landlords and bosses; as a competitive threat to American businesses that lead to unemployment and the closing of industries.

3) Perpetual or Forever Foreigner: The assumption that APAs are all new immigrants, and thus have not contributed to building this country, only "taking" from it. Consequently, they should not be entitled to the rights and privileges of citizenship and do not "belong" in this country.

These stereotypes have had tragic outcomes in American history, such as the Chinese Exclusion Act of 1882, the burning of APA towns across the west coast in the early 1900s, the unjust incarceration of largely American citizen Japanese Americans during WWII, the brutal, racially motivated murders of Vincent Chin in Detroit in 1982 and of Balbir Singh Sodhi in Arizona after 9/11, the deportations of Southeast Asian American refugees from the Viet Nam War, and many 
others. The difference with COVID-19 is that it is happening now. We can stop this violence, and we can reject hate, toward APAs or any other group. We cannot celebrate our essential workers, from healthcare workers to homecare workers to food industry workers, who are on the front lines saving lives and risking their lives, only to ignore the hate they and their communities are facing on the streets.

Like our communities, Black communities are heavily impacted by COVID-19. Black Americans have disproportionate rates of incidence, mortality, and economic impact. The historical criminalization of our brothers and sisters have compounded the issues of taking protective measures against the pandemic. For APAs, since the pandemic began, wearing a mask has been a potential marker of carrying disease or a marking of our bodies as targets of violence. Mundane daily activities put us at risk of hate speech or hate crimes. For Black community members, these daily activities not only have resulted in the heightened perpetuation of racist assumptions of criminality, the unfounded fears are compounded by the historical reality of police brutality and death. George Floyd's murder at the hands of the police is just one instance of systemic oppression articulated through the dehumanization of the black body. The fact that Mr. Floyd's murder included a Hmong American officer forces us to come to terms with an issue our communities have collectively tried to avoid the past forty-five years: where will we stand in the conversation of race and white supremacy in this country we have claimed as home? After fortyfive years, will our education, leadership, and activism be tools to perpetuate systems of white supremacy, or will we recognize how we have benefited from past social movements? Will we use these powers to stand in solidarity with communities of color against historical oppressions that have impacted all of us? Will we see our liberation as entwined in the liberation of intersectional Black, Brown, and Indigenous lives? These are the questions before our generation, and the story of how we chose to embody our refugee resilience in the fight for justice in the classrooms, in the institutions, and on the streets is for us to write.

In peace and solidarity,

Loan Thi Dao and Peter T. Keo 


\section{About the Editors}

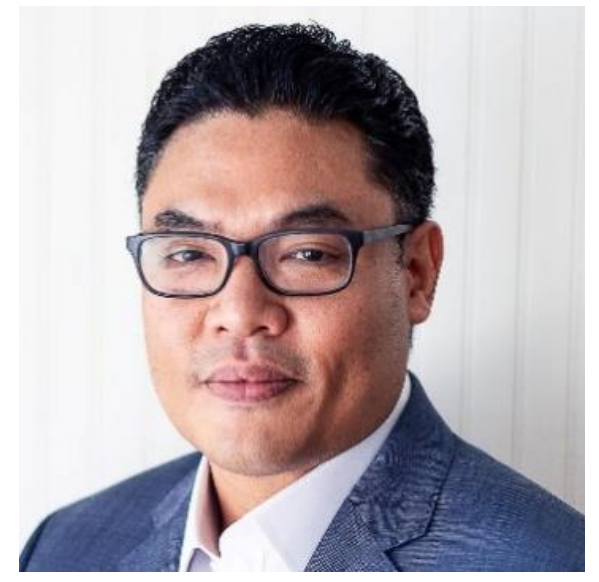

Peter T. Keo, EdD, is currently Senior Research Fellow at Stanford University's School of Medicine, Center for Compassion and Altruism Research and Education. His research is at the intersection of neuroscience, leadership, and K-12 educational outcomes for vulnerable students. He also conducts research on anti-racism, human rights, and democracy in post-war countries.

Dr. Keo holds a Doctorate in Education from Teachers College, Columbia University, in addition to master's degrees from Harvard University and the University of Chicago. He is certified in "Evaluating Social Programs Using Randomized Controlled Trials" from the Massachusetts Institute of Technology (MIT), through the Poverty Action Lab. He is a regular contributor to the Voice of America - Cambodia, and has provided media commentary for the Education Week, BBC, CSIS-Pacific Forum, The Diplomat, The Phnom Penh Post, The Cambodia Daily, and CCTV, among other outlets. He was appointed by the Governor to serve on the Teachers and Leaders Council in Nevada. His parents are Cambodian refugees.

He has held numerous executive and leadership roles including Senior Adviser (former Cambodian Minister of Education), Secretary-General (Asia Economic Forum), Vice President of Strategy (University of Cambodia), Director (RISE for Boys and Men of Color, University of Pennsylvania), Managing Director \& Chief Strategy Officer (Citizen Schools-Massachusetts), and other notable positions. At 23, he was the Assistant Director and Research Fellow of the Cambodian Institute for Cooperation and Peace, an ASEAN think tank to build peace and cooperation. He has also held senior-level academic appointments at UCLA and the University of Pennsylvania. He has served as Principal Investigator on research studies regarding the AsianAmerican community, and has published widely in editorials, books chapters, and peer-reviewed journals including Equity \& Excellence in Education.

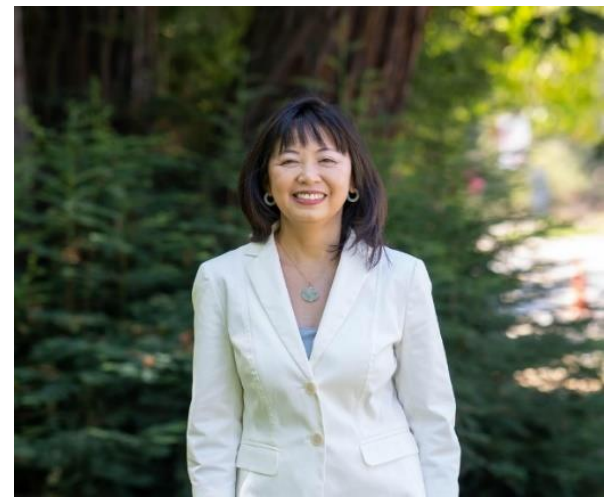

Loan Thi Dao, is an Associate Professor and Director of Ethnic Studies at St. Mary's College of California. She received her Ph.D. at the University of California Berkeley, in Ethnic Studies, and specializes in Southeast Asian refugee migration and community development, immigrant and refugee youth, social movements, and Community-Based Participatory Research (CBPR). Dao has published on topics related to memory and war in cultural productions, Vietnamese American female leadership, culturally competent services for elderly Vietnamese, undocumented AAPI activists, and the rise of a new generation of Southeast Asian American activists in the immigrant rights movement. She teaches interdisciplinary ethnic studies courses, and her service has included leadership positions in diversity and inclusion initiatives, immigrant rights and policy advocacy, and cultural productions. 


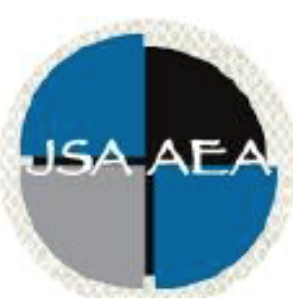

\title{
Journal of Southeast Asian American \\ Education and Advancement
}

Vol. 15 Iss. 2 Special Issue (2020) www.JSAAEA.org

Special Issue Co-Editors

Dr. Peter T. Keo

Stanford University

Dr. Loan Thi Dao

St. Mary's College of California

Editor

Dr. Wayne E. Wright

Purdue University

Associate Editors

Dr. Chhany Sak-Humphry

University of Hawaii at Manoa

Dr. Phitsamay Sychitkokhong Uy

University of Massachusetts, Lowell

\author{
Book Review Editor \\ Dr. Vichet Chhuon \\ University of Minnesota \\ Creative Works Editor \\ Bryan Thao Worra \\ Lao Assistance Center \\ Journal Manager \\ Fang Gao \\ Purdue University
}

Editorial Review Board

Dr. Steve Arounsack

California State University, Stanislaus

Dr. Sovicheth Boun

Salem State University
Dr. Carl L. Bankston III

Tulane University

Dr. Phala Chea

Lowell Public Schools 


\author{
Dr. Virak Chan \\ Purdue University \\ Dr. Loan Dao \\ St. Mary's College of California \\ Dr. Changming Duan \\ University of Missouri-Kansas City \\ Dr. Sothy Eng \\ Lehigh University \\ Dr. Vincent K. Her \\ University of Wisconsin, Eau Claire \\ Dr. Peter Nien-Chu Kiang \\ University of Massachusetts, Boston \\ Dr. Kevin K. Kumashiro \\ University of Illinois, Chicago \\ Dr. Ha Lam \\ Independent Scholar \\ Dr. Jonathan H. X. Lee \\ San Francisco State University \\ Dr. Monirith Ly \\ Royal University of Phnom Penh \\ Dr. Bic Ngo \\ University of Minnesota \\ Dr. Leakhena Nou \\ California State University, Long Beach \\ Dr. Mark Pfeifer \\ SUNY Institute of Technology \\ Dr. Loan T. Phan \\ University of New Hampshire \\ Dr. Karen Quintiliani \\ California State University, Long Beach \\ Dr. Angela Reyes \\ Hunter College \\ The City University of New York \\ Dr. Fay Shin \\ California State University, Long Beach \\ Dr. Christine Su \\ College of San Mateo \\ Dr. Alisia Tran \\ Arizona State University \\ Dr. Khatharya Um \\ University of California, Berkeley \\ Dr. Kim Tran \\ University of California, Los Angeles, \\ Glendale Community College \\ Dr. Molly Wiebie \\ The University of Texas at Austin
}

Dr. George Chigas

University of Massachusetts, Lowell

Dr. Hien Duc Do

San Jose State University

Dr. Sophal Ear

Occidental College

Dr. Jeremy Hein

University of Wisconsin, Eau Claire

Dr. Nancy H. Hornberger

University of Pennsylvania

Dr. Peter Tan Keo

Stanford University

Dr. Yvonne Kwan

San Jose State University

Dr. Ravy Lao

California State University, Los Angeles

Dr. Stacey Lee

University of Wisconsin, Madison

Dr. Sue Needham

California State University, Dominguez Hills

Dr. Max Niedzwiecki

Daylight Consulting Group

Dr. Clara Park

California State University, Northridge

Dr. Giang Pham

University of Massachusetts Amherst

Dr. Malaphone Phommasa

University of Clifornia Santa Barbara

Dr. Kalyani Rai

University of Wisconsin-Milwaukee

Dr. Cathy J. Schlund-Vials

University of Connecticut, Storrs

Dr. Nancy J. Smith-Hefner

Boston University

Dr. Yer J. Thao

Portland State University

Dr. Monica M. Trieu

Purdue University

Dr. Silvy Un

Saint Paul Public Schools

Dr. Linda Trinh Vo

University of California, Irvine

Dr. Yang Sao Xiong

The University of Wisconsin-Madison

Dr. Zha Blong Xiong

University of Minnesota 


\section{Doctoral Student Editorial Review Board}

\author{
Diana Chandara \\ University of Minnesota-TwinCiteis \\ Linh Dang \\ University of Rochester \\ Annie BichLoan Duong \\ San Joaquin County Office of Education \\ Jacqueline Mac \\ Indiana University \\ Vanessa Sovanika Na \\ University of California SanDiego \\ Khoi Nguyen \\ George Mason University \\ Linda Marie Pheng \\ University of Wisconsin-Madison \\ Latana Thaviseth \\ University of California Los Angeles \\ Melissa Vang \\ San Diego State University \\ Soua Xiong \\ San Diego State University \\ Claremont Graduate University
}

Kassandra Chhay

University of Minnesota-Twin Cities

Bao Diep

University of Minnesota-Twin Cities

Nielson Hul

Cornell University

Dung Minh Mao

University of Minnesota-Twin Cities

Hoa Nha Nguyen

Boston College

Thien-Huong Ninh

University of Southern California

Krissyvan Truong

Claremont Graduate University

Mai Vang

University of Massachusetts Boston

Thong Vang

University of Minnesota-Twin Cities 